\title{
Morphological variation in the testes and accessory sex organs of Australian rodents in the genera Pseudomys and Notomys
}

\author{
W. G. Breed
}

Department of Anatomy and Histology, University of Adelaide, Adelaide, South Australia 5001

\begin{abstract}
Summary. The relative size and histology of the testes of sexually active adult Pseudomys and Notomys differed markedly between species. Average weight of testes (as \% of body wt) ranged from about $3 \%$ in $P$. australis and $P$. nanus to about $0.15 \%$ in most Notomys. In the testes of most species, interstitial tissue was relatively sparse, but in $P$. apodemoides, $P$. delicatulus and $P$. hermannsburgensis it was abundant and consisted of a mass of lipid-rich epithelioid Leydig cells. Seminiferous tubule diameters were similar in all species, but epididymides ranged from about $500 \mathrm{mg}$ in weight (about $1 \%$ body wt) in $P$. australis to about $20 \mathrm{mg}$ (about $0.05 \%$ body wt) in most Notomys. Likewise numbers of spermatozoa in the paired cauda epididymidis ranged from about $500 \times$ $10^{6}$ in $P$. australis and $P$. nanus to about $2 \times 10^{6}$ in 3 of 4 Notomys species.
\end{abstract}

\section{Introduction}

In Australia there are two related genera of relatively small native rodents, the Pseudomys or 'mouse-like' species and the Notomys or hopping mice (F. Muridae), but there is little information on the anatomy or histology of the testes and accessory sex glands of most of these species. Taylor \& Horner $(1970,1972)$ found large scrotal testes, with histology similar to that of Rattus, in Pseudomys gracilicaudatus and $P$. hermannsburgensis, but in reproductively active $P$. delicatulus small testes with extensive interstitial tissue were observed. Taylor \& Horner (1972) also concluded that the male accessory sex glands of $P$. gracilicaudatus and $P$. shortridgei were similar to those of the laboratory rat, except for the apparent absence of coagulating glands. By contrast, 3 of 4 species of Notomys have extremely small testes and an arrangement of the male accessory sex glands in which the ventral prostate is the only large gland found (Breed, 1980, 1981a). The present study was therefore carried out to investigate more extensively the interspecific variation in testes, epididymides, seminal vesicles, coagulating glands and ventral prostates in all available Pseudomys and Notomys species.

\section{Materials and Methods}

Many of the Australian non-Rattus rodents are rare and/or sparsely distributed and few species are bred routinely in captivity. In the present study, some of the animals used were laboratory bred adults, of known age, maintained singly or with an adult female in a controlled laboratory environment of 14-h light, 10 -h dark and at a regulated temperature of about $23^{\circ} \mathrm{C}$ (see Table 1). Others were wild-caught individuals that had then been kept in the controlled laboratory environment or 
had been killed at the time of capture and stored in $70 \%$ alcohol in the South Australian Museum (S.A.M.) mammal collection. In the latter case data were only analysed if pregnant and/or oestrous females had also been collected at the same time. For origin of many of these animals see Morrissey \& Breed (1982).

\section{Preparation of material}

Animals were anaesthetized with pentobarbitone sodium (Nembutal) or halothane (Fluothane). From some, one testis was removed, immediately immersed in $3 \%$ glutaraldehyde/formalde-

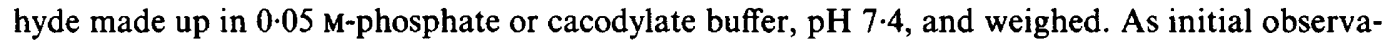
tions indicated similar testis size on both sides, the weight of the one testis was doubled to give the approximate weight of the testes for the animal. Other individuals were perfused with the same fixative through the left ventricle. Testes were subsequently post-fixed in osmium tetroxide and embedded in Spurr's resin; 0.5-1 $\mu \mathrm{m}$ plastic sections were cut on an ultramicrotome and stained with toluidene blue in borate buffer. The sections were observed with $\times 10$ objective on a Wild, semi-automatic, sampling microscope containing a Weibel graticule to determine the approximate relative volume of interstitial tissue by a standard point counting procedure (Weibel, Kistler \& Scherle, 1966): an average of 277 points were counted for each specimen. Subsequently, diameters were determined of at least 4 seminiferous tubules cut in cross-section from each testis. Reproductive tracts were also removed and immersed in buffered formaldehyde. Subsequently, seminal vesicles, coagulating and ventral prostate glands were dissected out and weighed.

From some of the non-perfused animals, epididymal weights were determined and spermatozoa were counted in the caput plus corpus and cauda epididymidis. For this, the tissue was placed in $0.5-3 \mathrm{ml}$ saline $(9 \mathrm{~g} \mathrm{NaCl} / 1)$ to which had been added a little hyaluronidase. The tissue was macerated, and $0.01 \mathrm{ml}$ sperm suspension was diluted to 0.1 or $1.0 \mathrm{ml}$ with $10 \%$ formalin for counting in a haemocytometer. The final figure was adjusted after taking into account the initial dilution. If sperm counts were not performed, a small piece of vas deferens or cauda epididymidis was removed and its contents were either squeezed onto a microscope slide flooded with $3 \%$ buffered glutaraldehyde/formaldehyde or into a watch glass containing saline. An animal was considered sexually mature if abundant, intact spermatozoa of normal appearance were found. Only testes from such animals were sectioned and analysed in the present study. Reproductive organs of the wild-caught animals that had been preserved in $70 \%$ alcohol in the South Australian Museum were also dissected out and weighed. None of the latter tissue was used for histology.

\section{Results}

\section{Tësticular weights}

The paired testicular weights of the Pseudomys individuals were generally consistent within species in spite of the material being derived from several sources and being exposed to different fixatives for varying periods of time. The values ranged from about 0.3 to $4.0 \%$ relative to body weight for the various species (Table 1). In animals from 3 of 4 Notomys species studied, testes were invariably very small and usually did not exceed $0.2 \%$ body weight regardless of the age or history of the animals but that of the fourth species was about $0.6 \%$ body weight (Table 1 ).

\section{Testicular histology}

Full spermatogenesis and various germ cell associations could always be seen regardless of relative testicular size. Seminiferous tubules showed only little variation between species and were usually between 200 and $240 \mu \mathrm{m}$ in diameter (see Table 2). 
Table 1. Absolute and relative testes weights in adult male Pseudomys and Notomys

\begin{tabular}{|c|c|c|c|c|c|}
\hline Species & $\begin{array}{c}\text { Age } \\
\text { (months) }\end{array}$ & No. & $\begin{array}{l}\text { Body wt } \\
(\mathrm{g})^{*}\end{array}$ & $\begin{array}{l}\text { Wt of } \\
\text { testes } \\
(\mathrm{mg})^{*}\end{array}$ & $\begin{array}{c}\text { Relative } \\
\text { testicular wt } \\
\text { (mean and range) }\end{array}$ \\
\hline Pseudomys apodemoides & $\begin{array}{l}4-8 \\
+ \\
++\end{array}$ & $\begin{array}{l}3 \\
5 \\
1\end{array}$ & $\begin{array}{l}31 \pm 11 \\
22 \pm 7 \\
21\end{array}$ & $\begin{array}{c}141 \pm 24 \\
113 \pm 18 \\
143\end{array}$ & $\begin{array}{l}0.5(0.3-0.7) \\
0.5(0.3-0.7) \\
0.7\end{array}$ \\
\hline$P$. australis & $\begin{array}{c}4-5 \\
6-9 \\
13-20\end{array}$ & $\begin{array}{l}5 \\
5 \\
4\end{array}$ & $\begin{array}{l}55 \pm 5 \\
63 \pm 5 \\
59 \pm 9\end{array}$ & $\begin{array}{l}1853 \pm 254 \\
2155 \pm 127 \\
2242 \pm 129\end{array}$ & $\begin{array}{l}3.4(2.5-4.2) \\
3.5(3.0-4.0) \\
3.8(3.4-4.9)\end{array}$ \\
\hline P. delicatulus & $\begin{array}{l}17 \\
+\end{array}$ & $\begin{array}{l}1 \\
4\end{array}$ & $9^{8} \pm 0.6$ & $\begin{array}{c}50 \\
43 \pm 2\end{array}$ & $\begin{array}{l}0.6 \\
0.5(0.4-0.5)\end{array}$ \\
\hline$P$. desertor & + & 2 & $39 \pm 1$ & $558 \pm 82$ & $1 \cdot 4,1 \cdot 5$ \\
\hline$P$. gracilicaudatus & + & 2 & $105 \pm 17$ & $1084 \pm 78$ & $1 \cdot 1,0.9$ \\
\hline P. hermannsburgensis & $\begin{array}{c}9 \\
+ \\
++\end{array}$ & $\begin{array}{r}1 \\
3 \\
10\end{array}$ & $\begin{array}{c}12 \\
18 \pm 6 \\
15 \pm 1 \cdot 5\end{array}$ & $\begin{array}{c}133 \\
163 \pm 54 \\
128 \pm 27\end{array}$ & $\begin{array}{l}1.1 \\
0.9(0 \cdot 7-1 \cdot 1) \\
0.9(0.6-1 \cdot 3)\end{array}$ \\
\hline$P$. nanus & $\begin{array}{c}5-6 \\
19-22\end{array}$ & $\begin{array}{l}4 \\
2\end{array}$ & $\begin{array}{l}70 \pm 16 \\
78 \pm 12\end{array}$ & $\begin{array}{l}1782 \pm 588 \\
1874 \pm 47\end{array}$ & $\begin{array}{l}2 \cdot 5(1 \cdot 8-3 \cdot 6) \\
2 \cdot 0,2 \cdot 9\end{array}$ \\
\hline P. novaehollandiae & + & 2 & $19 \pm 3$ & $71 \pm 9$ & $0 \cdot 3,0 \cdot 4$ \\
\hline P. shortridgei & + & 3 & $78 \pm 15$ & $345 \pm 53$ & $0.4(0.3-0.5)$ \\
\hline Notomys alexis & $\begin{array}{c}3-4 \\
6-9 \\
19-25 \\
++\end{array}$ & $\begin{array}{l}7 \\
6 \\
5 \\
7\end{array}$ & $\begin{array}{l}30 \pm 6 \\
28 \pm 2 \\
34 \pm 6 \\
31 \pm 4\end{array}$ & $\begin{array}{l}41 \pm 11 \\
43 \pm 6 \\
50 \pm 12 \\
36 \pm 7\end{array}$ & $\begin{array}{l}0.13(0.10-0.21) \\
0.15(0.11-0.20) \\
0.14(0.10-0.19) \\
0.12(0.11-0.14)\end{array}$ \\
\hline N. mitchelli & $\begin{array}{c}6-7 \\
11-16 \\
++\end{array}$ & $\begin{array}{l}4 \\
6 \\
6\end{array}$ & $\begin{array}{l}34 \pm 7 \\
39 \pm 7 \\
45 \pm 6\end{array}$ & $\begin{array}{l}74 \pm 10 \\
62 \pm 11 \\
57 \pm 18\end{array}$ & $\begin{array}{l}0.21(0.16-0.26) \\
0.16(0.11-0.19) \\
0.13(0.09-0.20)\end{array}$ \\
\hline N. fuscus & + & 1 & 44 & 67 & $0 \cdot 15$ \\
\hline N. cervinus & + & 2 & $33 \pm 1$ & $198 \pm 28$ & $0.64,0.53$ \\
\hline
\end{tabular}

* Values are mean \pm s.d.

+ Wild-caught individuals maintained in the laboratory for at least 5 months.

++ Wild-caught individuals killed in the field; pregnant or oestrous females also present in field sample at the same time.

Table 2. Testicular histology of Pseudomys and Notomys

\begin{tabular}{lccc}
\hline \multicolumn{1}{c}{ Species } & No. & $\begin{array}{c}\text { Relative vol. } \\
\text { occupied by } \\
\text { interstitial } \\
\text { tissue }(\%)^{*}\end{array}$ & $\begin{array}{c}\text { Diam. of } \\
\text { seminiferous } \\
\text { tubules } \\
(\mu \mathrm{m}) \dagger\end{array}$ \\
\hline$P$. apodemoides & 7 & $29.0(21-37)$ & $231 \pm 17$ \\
$P$. australis & 6 & $4.9(3-7)$ & $232 \pm 15$ \\
$P$. delicatulus & 3 & $27.8(24-36)$ & $204 \pm 24$ \\
$P$. desertor & 2 & $5.4(5-6)$ & $197 \pm 32$ \\
$P$. hermannsburgensis & 5 & $17.9(11-23)$ & $226 \pm 20$ \\
$P$. namus & 5 & $4.4(4-6)$ & $241 \pm 15$ \\
$P$. novaehollandiae & 2 & $7.0(6-8)$ & $184 \pm 10$ \\
$P$. shortridgei & 3 & $4 \cdot 2(2-6)$ & $201 \pm 13$ \\
$N$. alexis & 7 & $8.9(5-13)$ & $203 \pm 13$ \\
$N$. mitchelli & 4 & $11.9(8-17)$ & $206 \pm 13$ \\
$N$. fuscus & 2 & $14.4(12-16)$ & $217 \pm 3$ \\
$N$. cervinus & 2 & $14.9(14-16)$ & $221 \pm 4$ \\
\hline
\end{tabular}

* Mean (range).

$\uparrow$ Mean \pm s.d. 
Intraspecific variation in testicular histology was minimal at the time of death, irrespective of the age or history of the animals, but there were large interspecific differences. In $P$. nanus (Pl 1, Figs 1 \& 2), P. australis, P. desertor, P.novaehollandiae (Pl. 1, Fig. 3) and P. shortridgei (Pl. 1, Fig. 4) the interstitial tissue was relatively sparse and its relative volume did not exceed $8 \%$ (see also Table 2). A few Leydig cells were usually clustered around capillaries, while lymphatic channels were often seen between the Leydig cells and the myoid layer surrounding the tubules (Pl. 1, Figs $2 \& 4$ ). A continuous parietal endothelium lay close to the myoid cells. The surface of the Leydig cells that abutted the lymphatic space often had long microvilli.

In the testes of the other Pseudomys examined, the interstitial tissue was invariably much more abundant. In $P$. hermannsburgensis (Pl. 1, Figs $5 \& 6$ ) its relative volume was 11 to $23 \%$, whereas in wild-caught and laboratory bred $P$. delicatulus (P1. 2, Figs 7 and 8 ) and $P$. apodemoides $(\mathrm{Pl}$. 2, Figs 9 $\& 10$ ) it was $21-37 \%$ of the total testicular volume (see Table 2). In these 3 species there was invariably a mass of lipid-rich epithelioid Leydig cells. Some were binuclear, but, in most, a single more or less central nucleus and often a prominent nucleolus was visible (Pl. 2, Figs 8 \& 10). Occasional blood channels were evident, but lymphatics were generally rare or non-existent.

In Notomys the relative volume of interstitial tissue varied but, on average, was about $10 \%$ (Table 2; Pl. 2, Fig. 11). Most of this tissue was composed of lipid-rich Leydig cells (Pl. 2, Fig. 12). Blood channels could usually be seen amongst each group of Leydig cells and lymphatic channels were sometimes present near the tubules.

\section{Epididymal weights and number of spermatozoa}

Total weight of the epididymides ( \pm s.d.) was $28 \pm 6 \mathrm{mg}(n=3)$ in $P$. apodemoides, $552 \pm 56 \mathrm{mg}$ $(n=6)$ in $P$. australis, $23 \pm 10 \mathrm{mg}(n=8)$ in $P$. hermannsburgensis, $102 \mathrm{mg}(n=1)$ in $P$. shortridgei, $18 \pm 4 \mathrm{mg}(n=8)$ in $N$. alexis, $27 \pm 10 \mathrm{mg}(n=6)$ in $N$. mitchelli, $20 \mathrm{mg}(n=1)$ in $N$. fuscus and 58 $\mathrm{mg}(n=1)$ in $N$. cervinus.

Spermatozoa were invariably more numerous in the cauda than in the caput plus corpus epididymidis and the number present in the excurrent ducts correlated, in general, with the relative size of the epididymides and testes (Table 3).

\section{PLATE 1}

Fig. 1. Testis from Pseudomys nanus showing relatively sparse interstitial tissue (IT) between the seminiferous tubules $(\mathrm{ST}) . \times 225$.

Fig. 2. Interstitial tissue between 3 adjacent seminiferous tubules from $P$. nanus showing small blood vessels (BV) lacking blood cells due to perfusion, surrounded by a group of Leydig cells. Lymphatic spaces (LS) occur close to the tubules around which a myoid cell layer (MC) occurs. $\mathrm{SC}=$ Sertoli cell nucleus or abnormal spermatogonium, $\mathrm{St}=$ spermatids. $\times 2250$.

Fig. 3. Testes from $P$. novaehollandiae are relatively small and there is sparse interstitial tissue (IT) between the tubules (ST). $\times 225$.

Fig. 4. Interstitial tissue from $P$. shortridgei is sparse and made up of few Leydig cells (LC) surrounding blood vessels $(\mathrm{BV})$ between seminiferous tubules. $\times 2250$.

Fig. 5. Testis from $P$. hermannsburgensis has much interstitial tissue (IT) between the seminiferous tubules (ST). Blood vessels (BV) lack cells due to perfusion. $\times 225$.

Fig. 6. Interstitial tissue from $P$. hermannsburgensis is composed of abundant Leydig cells (LC) with numerous lipid droplets. There are occasional blood vessels (BV), but few lymphatic spaces. $\times 4500$. 

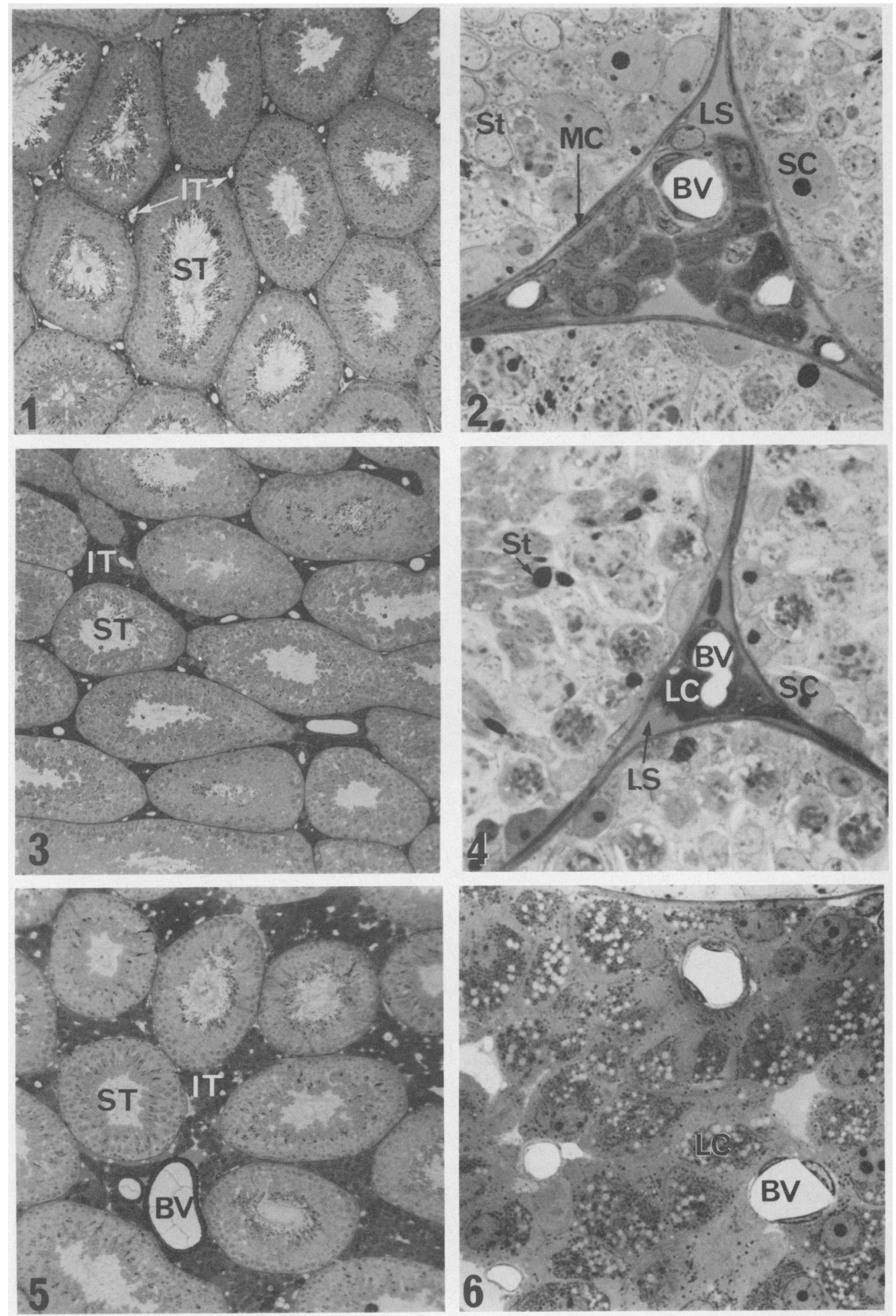

(Facing p. 610) 
PLATE 2
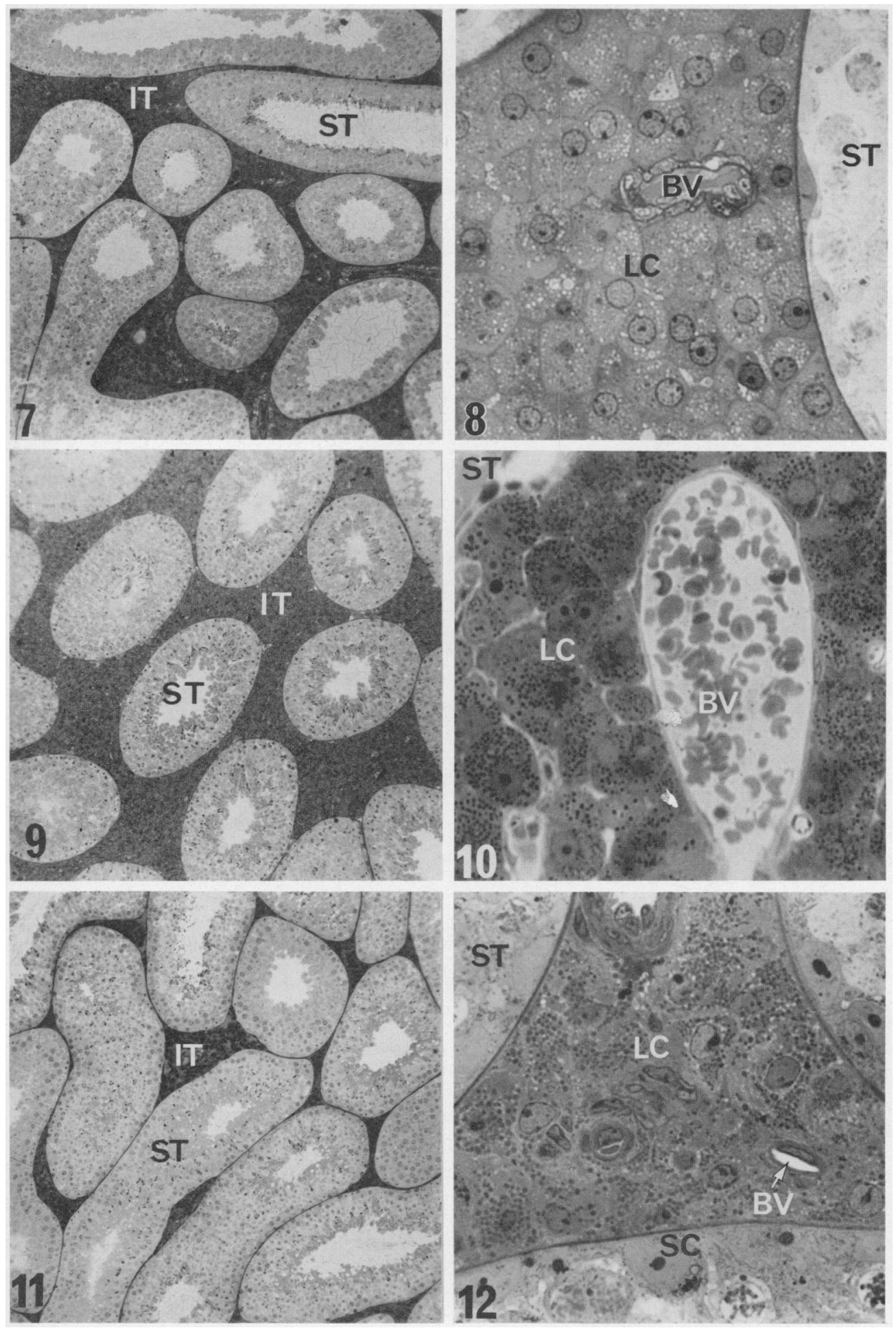
Table 3. Numbers of spermatozoa in the epididymides in several species of Pseudomys and Notomys

\begin{tabular}{|c|c|c|c|c|}
\hline \multirow[b]{2}{*}{ Species } & \multirow{2}{*}{$\begin{array}{c}\text { Age } \\
\text { (months) }\end{array}$} & \multirow[b]{2}{*}{ No. } & \multicolumn{2}{|c|}{ No. of spermatozoa $\left(\times 10^{6}\right)$ in: } \\
\hline & & & Caput + corpus & Cauda \\
\hline Pseudomys apodemoides & - & $4^{*}$ & $3 \pm 1$ & $10 \pm 2$ \\
\hline P. australis & $\begin{array}{c}5-7 \\
8-9 \\
13-18\end{array}$ & $\begin{array}{l}3 \\
5 \\
3\end{array}$ & $\begin{array}{l}68 \pm 21 \\
73 \pm 22 \\
93 \pm 5\end{array}$ & $\begin{array}{l}387 \pm 33 \\
514 \pm 86 \\
483 \pm 24\end{array}$ \\
\hline P. hermannsburgensis & - & 1 & 11 & 20 \\
\hline P. nanus & - & 6 & $94 \pm 28$ & $387 \pm 153$ \\
\hline P. shortridgei & - & 2 & $-\dagger$ & $51 \pm 30$ \\
\hline Notomys alexis & $\begin{array}{c}3-5 \\
6-9 \\
19-28\end{array}$ & $\begin{array}{l}7 \\
6 \\
5\end{array}$ & $\begin{array}{l}0.5 \pm 0.3 \\
0.7 \pm 0.3 \\
0.9 \pm 0.1\end{array}$ & $\begin{array}{l}1.3 \pm 0.6 \\
2.3 \pm 1.4 \\
2.6 \pm 0.7\end{array}$ \\
\hline N. mitchelli & - & 4 & $1.8 \pm 1.6$ & $1.8 \pm 0.5$ \\
\hline N. fuscus & - & 1 & 1.6 & $2 \cdot 0$ \\
\hline N. cervinus & - & 1 & $10 \cdot 9$ & $21 \cdot 4$ \\
\hline
\end{tabular}

Values are mean \pm s.d. for 2 epididymides per animal.

* 2 wild caught animals were 6 months old.

$\uparrow$ Not recorded.

Accessory sex gland weights

$P$. australis and $P$. numus had relatively large seminal vesicles and coagulating glands but small ventral prostate glands (Table 4). In the other Pseudomys species the seminal vesicles and coagulating glands were generally slightly smaller relative to body weights. In most of these species ventral prostate glands were als 6 small, except in the two $P$. novaehollandiae in which relatively large glands occurred. In three Notomys species a markedly different arrangement of accessory glands occurred: the seminal vesicles and coagulating glands were minute and did not exceed $3 \mathrm{~mm}$ in length in $N$. alexis and $5 \mathrm{~mm}$ in $N$. mitchelli, but relatively large ventral prostate glands were present (see Table

\section{PLATE 2}

Fig. 7. Testis from $P$. delicatulus has very extensive interstitial tissue (IT) between seminiferous tubules (ST). $\times 225$.

Fig. 8. Interstitial tissue from $P$. delicatulus is composed of abundant, lipid-rich, Leydig cells (LC) with spherical central nuclei and often a prominent nucleolus. Occasional blood vessels (BV) here shown as small arteriole occurred, but lymphatics were rare. $\times 1800$.

Fig. 9. Testes from $P$. apodemoides also has very extensive interstitial tissue (IT) occurring between the seminiferous tubules (ST). $\times 225$.

Fig. 10. Interstitial tissue from $P$. apodemoides is composed of a mass of epithelioid lipid rich Leydig cells (LC) between the seminiferous tubules (ST), blood vessels (BV) like that shown here, occurred only occasionally. $\times 1800$.

Fig. 11. Testis from Notomys alexis is extremely small. There is variable amount of interstitial tissue (IT) between the seminiferous tubules $(\mathrm{ST}) . \times 225$.

Fig. 12. Interstitial tissue of $N$. alexis is often composed of fairly abundant Leydig cells (LC) amongst which small blood vessels (BV), and occasional lymphatic spaces, usually lying close to the myoid cell layer, occur. $\mathrm{SC}=$ Sertoli cell, $\mathrm{ST}=$ seminiferous tubule. $\times 2250$. 
Table 4. Absolute and relative accessory sex gland weights of Pseudomys and Notomys

\begin{tabular}{|c|c|c|c|c|}
\hline Species & No. & $\begin{array}{c}\text { Seminal vesicles } \\
(\mathrm{mg})\end{array}$ & $\begin{array}{l}\text { Coagulating glands } \\
(\mathrm{mg})\end{array}$ & $\begin{array}{l}\text { Ventral prostate } \\
\text { (mg) }\end{array}$ \\
\hline P. apodemoides & 7 & $142 \pm 38 \quad(0 \cdot 3-0 \cdot 6)$ & $18 \pm 3(0.05-0.11)^{*}$ & $12 \pm 3(0.02-0.09)^{*}$ \\
\hline P. australis & 13 & $865 \pm 191(1 \cdot 0-1 \cdot 7)$ & $272 \pm 79(0.22-0.54)$ & $90 \pm 30(0.09-0 \cdot 18)$ \\
\hline P. delicatulus & 3 & $(0 \cdot 3-0 \cdot 4)$ & $18(0.2) \dagger$ & $10(0 \cdot 1) \dagger$ \\
\hline$P$. desertor & 1 & $202(0.5)$ & $56(0 \cdot 1)$ & $22(0.04)$ \\
\hline P. hermannsburgensis & 7 & $122 \pm 42 \quad(0.4-0.9)$ & $22 \pm 12(0.05-0.13)$ & $48 \pm 10(\sim 0.2)$ \\
\hline P. nanus & 6 & $694 \pm 98 \quad(0 \cdot 6-1 \cdot 2)$ & $257 \pm 79(0.2-0.6)$ & $97 \pm 30(0 \cdot 1-0 \cdot 2)$ \\
\hline P. novaehollandiae & 2 & $86 \pm 2 \quad(0.4,0.6)$ & $32 \pm 0 \quad(0 \cdot 1,0.2)$ & $65 \pm 21(0.3,0.4)$ \\
\hline$P$. shortridgei & 2 & $222 \pm 96 \quad(0 \cdot 1,0 \cdot 4)$ & $60 \pm 34(0.11,0.03)$ & $20 \pm 4(0.01,0.03)$ \\
\hline N. alexis & 12 & $-\ddagger$ & $-\ddagger$ & $105 \pm 38(0 \cdot 2-0 \cdot 6)$ \\
\hline$N$. mitchelli & 8 & $-\ddagger$ & $-\ddagger$ & $174 \pm 64(0 \cdot 2-0 \cdot 6)$ \\
\hline N. fuscus & 1 & $-\ddagger$ & $-\ddagger$ & $90(0 \cdot 2)$ \\
\hline N. cervinus & 2 & $182 \pm 52(0.7,0 \cdot 4)$ & $25 \pm 5 \quad(0 \cdot 08,0 \cdot 06)$ & $106 \pm 3(0 \cdot 3,0 \cdot 3)$ \\
\hline
\end{tabular}

Values are mean \pm s.d. with range of relative weights expressed as $\%$ body weight in parentheses.

* Determined for $\overline{4} / 7$ animals.

+ Determined for $1 / 3$ animals.

\$ Rudimentary.

4), by contrast in $N$. cervinus there were both large seminal vesicles and coagulating glands similar to those in Pseudomys.

\section{Discussion}

The testes of all the animals investigated had large canalised seminiferous tubules with all stages of spermatogenesis indicating sexual maturity. Nevertheless, within these species of Australian rodents there are considerable differences in relative testicular size and histology, epididymal weight, and number of spermatozoa present. In some Pseudomys (e.g. P. australis) there are very large testes, sparse interstitial tissue and very large sperm stores. Others, e.g. $P$. delicatulus, $P$. hermannsburgensis and $P$. apodemoides, have small or medium-sized testes with much interstitial tissue made up of abundant Leydig cells and fairly low sperm stores, whereas 3 out of 4 Notomys have minute testes and extremely low sperm stores.

Interspecific variation in amount and organization of the testicular interstitial tissue has been shown for at least two other mammalian groups (see Fawcett, Neaves \& Flores, 1973; Setchell, 1977) but abundant interstitial tissue in rodents has been documented for only one other species, the naked mole rat, Heterocephalus glaber (Fawcett et al., 1973).

Harcourt, Harvey, Larson \& Short (1981) have shown that, in primates, relative testicular size correlates with the breeding system. In multimale breeding groups there were relatively larger testes, and Harcourt et al. (1981) suggested that such trends might also occur in other mammalian orders. Amongst the Australian rodents $P$. australis probably occurs in groups, has a social hierarchy (Watts \& Aslin, 1981), and sexual dimorphism of body weight (Smith, Watts \& Crichton, 1972), suggesting a polygynous mating system. By contrast, $P$. desertor individuals probably occur in isolation except at the time of mating, whereas $P$. shortridgei may form pair bonds and thus could be monogamous (Happold, 1976). In $P$. apodemoides there is relatively little aggression between males when placed together and, in the wild, more than one reproductively active adult of each sex is sometimes found in the one burrow system. A promiscuous mating strategy has thus been suggested (Happold, 1976; Cockburn, 1981). N. alexis also breeds communally in the wild. In the laboratory, no pair bonding is evident but a high degree of cohesion occurs between all animals kept together in the same group. No social order between cohabiting males is apparent, and when a female comes into oestrus she is followed by several males until one achieves intromission or ejaculation (Happold, 1976). A promiscuous reproductive strategy also seems likely for this species. Thus within 
these Australian rodents the information presently available suggests a possible relationship between relative testicular size and breeding system; amongst the species that tend to occur communally, the smallest testes are present in those that probably exhibit the lowest levels of intermale aggression.

All accessory sex organs, including coagulating glands, were found in all the Pseudomys examined, contrary to the previous observations of Taylor \& Horner (1972). However, the species with the relatively small testes generally had smaller glands. Although this could indicate lack of full sexual maturity in these animals it seems unlikely, at least for the $P$. apodemoides individuals, as adult wild-caught males were obtained at times when all females were pregnant and/or lactating, and also adult laboratory-bred animals had similar weights. Amongst Notomys, $N$. cervinus has a typical murid arrangement of accessory sex glands similar to that of Pseudomys, but in the other 3 species the ventral prostate is the only large gland present. Lack of development of the seminal vesicles and coagulating glands appears to preclude the formation of a vaginal plug (Breed, 1981a, b), which has been documented for $N$. cervinus (Crichton, 1974). Why such divergence in the arrangement of the accessory sex glands has evolved between these species remains to be determined, but it is evident that the relative size of the seminal vesicles and coagulating glands in Notomys correlates with that of the testes.

I thank Dr P. Baverstock and Dr C. Watts, Institute of Medical and Veterinary Science, Adelaide; Dr B. Fox, Department of Zoology, University of New South Wales, Sydney; Dr S. Morton of East Jabiru, Northern Territory; Mr K. Johnson, Conservation Commission of the Northern Territory, and Mr P. Aitken, South Australian Museum, for some of the animals; Mr C. Leigh, Department of Anatomy for help with the sectioning; Mrs G. Hermanis, Mrs J. Brazier, Mrs B. Sheldon and Mr R. Murphy, Department of Anatomy, for assistance; Dr D. Brooks and Mr J. Thompson for advice on sperm counting procedures; and Dr B. P. Setchell and Dr B. Firth for helpful comments on the manuscript.

\section{References}

Breed, W.G. (1980) Further observations on spermatozoal morphology and male reproductive tract anatomy of Pseudomys and Notomys species (Mammalia: Rodentia). Trans. Roy. Soc. S. Aust. 104, 51-55.

Breed, W.G. (I 981a) Unusual anatomy of male reproductive tract in Notomys alexis. J. Mammal. 62, 373-375.

Breed, W.G. (1981b) Histology of accessory sex organs and extragonadal sperm reserves in the male hopping mouse Notomys alexis. Arch. And. 7, 357-360.

Cockburn, A. (1981) Population processes of the silky desert mouse Pseudomys apodemoides in mature heathlands. Aust. Wildl. Res. 8, 499-514.

Crichton, E.G. (1974) Aspects of reproduction of the genus Notomys (Muridae). Aust. J. Zool. 22, 439-447.

Fawcett, D.W., Neaves, W.B. \& Flores, M.N. (1973) Comparative observations on intertubular lymphatics and the organisation of the interstitial tissue of the mammalian testis. Biol. Reprod. 9, 500-532.

Happold, M. (1976) Social behaviour of the conilurine rodents (Muridae) of Australia. Z. Tierpsychol. 40, 113-182.

Harcourt, A.H., Harvey, P.H., Larson, S.G. \& Short, R.V. (1981) Testis weight, body weight and breeding systems in primates. Nature, Lond. 293, 55-57.

Morrissey, B.L. \& Breed, W.G. (1982) Variation in exter- nal morphology of the glans penis of Australian native rodents. Aust. J. Zool. 30, 495-502.

Setchell, B.P. (1977) Reproduction in male marsupials. In The Biology of Marsupials, pp. 411-457. Eds B. Stonehouse \& D. Gilmore. Macmillan, London.

Smith, J.R., Watts, C.H.S. \& Crichton, E.G. (1972) Reproduction in the Australian rodents Notomys alexis and Pseudomys australis (Muridae). Aust. Mamm. 1, $1-7$.

Stanley, M. (1971) An ethogram of the hopping mouse, Notomys alexis. Z. Tierpsychol. 29, 225-258.

Taylor, J.M. \& Horner, B.E. (1970) Observations on reproduction in Leggadina (Rodentia: Muridae). $J$. Mammal. 51, 10-17

Taylor, J.M. \& Horner, B.E. (1972) Observations on the reproductive biology of Pseudomys (Rodentia: Muridae). J. Mammal. 53, 318-328.

Watts, C.H.S. \& Aslin, H.J. (1981) The Rodents of Australia. Angus and Robertson, London.

Weibel, E.R., Kistler, G.S. \& Scherle, W.F. (1966) Practical stereological methods for morphometric cytology. J. Cell Biol. 30, 23-38.

Received 1 March 1982 